\title{
The Japanese Land Problem of California
}

\author{
By Elwood MEAD ${ }^{1}$ \\ Professor of Rural Institutions, University of California
}

$\mathrm{T}$ HE most keenly contested issue of the recent election in California was over the action which should be taken on the initiative amendment prohibiting the selling or leasing of land to Japanese. Compared to this, interest as to who was to be president, or whether America would belong to the League of Nations was vague and remote. To many white farmers the vote on this amendment would determine whether they would continue to live on their farms or have to sell to an Oriental. The vote was therefore large. Public opinion was thoroughly aroused, and the majority of over three to one for the amendment showed clearly the trend of public opinion.

This legislation is a farmers' movement. It was opposed by some landowners and by many who believe in the complete exclusion of the Japanese but who did not believe that this was the way to secure national action. Organized labor was divided on the issue as were business men in cities. The San Francisco Chamber of Commerce opposed the amendment and there were placards in some towns advising laborers and business men to vote "no" since its adoption would, as they naively put it, drive the Japs into town to compete with the townspeople.

There was practically no division of opinion among country people who have to compete with the Japs. They worked and voted for the amendment. The white farm laborer does not like to work with them and still less to work for them. The white tenant farmer knows they have made his lot harder by forcing him to pay higher rent. The farmer living on his own

${ }^{1}$ Author of Irrigation Institutions. land fears their invasion of his section and their organized campaigns for exclusive control of land and the marketing of products.

For this action, and the feeling that lies back of it, the Japanese are responsible. The California farmer is easy-going and optimistic, not inclined to plan for the future. If during the last ten years the Japanese had gone into the farming districts as individuals and mingled with white farmers as individuals, there would today be no more prejudice against them as a race than there is against Swedes or Italians, which is none at all. The statement that they have not done so, but have sought to establish themselves as racial communities, is not made in the way of criticism but to help explain why Japanese land ownership is objected to.

In Placer County, for example, 15,000 out of 19,000 irrigated acres are leased or owned by Japanese. The fine homes of the former white tenants are empty. They shelter rats and owls. So far as white people are concerned the towns are socially dead. The irrigated part of Placer County is practically a little Japan. The people from Nippon dominate its life. Controlling the land, they can perpetuate the ideas, habits, religion and loyalities of the mother country and do this indefinitely.

If the Italians owned 80 per cent of the tomato crop of the Sacramento District and 79 per cent of the Turlock District, and exercised a similar control over many other important fruit and vegetable products, they would be regarded with the same apprehension as are the Japanese. The good stand- 
ing of the one and the unpopularity of the other is due quite largely to the fact that the first mingles with Americans and makes himself a part of the American life of California. The other seeks to create and is creating a racial life of his own.

Last February, I attended a meeting of farmers called to discuss a resolution pledging landowners in that locality to refuse to lease land to Japanese. There was a considerable sprinkling of business men from the nearest town and most of the landowners were present. Japanese settlement in this area, which is a part of a melon-growing district, dated back only three years. In that time Japanese settlement had grown so rapidly that the previous year over 60 per cent of the melon crop had been grown by this race. Over 60 per cent of the melon shipments were handled by a commission firm with whom the Japanese did business. A similar growth for another two seasons would mean that the melon business would be to the white grower only a memory. The white farmers met to consider whether they would abdicate and move out or take steps to end this invasion.

When the meeting opened the discussion was entirely in favor of the Japanese. The first speaker announced he was there to "declare himself." $\mathrm{He}$ said he was renting land to the Japanese as a business proposition and he intended to continue to do so; that before the Japs came he was glad to get $\$ 15$ an acre cash rent, now he was getting $\$ 40$ an acre, and he owed the increase to the Japs. $\mathrm{He}$ further stated that before brown men came into the neighborhood, land was selling for $\$ 100$ an acre. They had offered him $\$ 250$ an acre, and he proposed to deal where he could make the most money. The land was his own. Now was his time to make hay and so far as he was concerned the Japanese were the haymakers. It was not his business to sacrifice money to keep California white.

Other landowners made similar declarations and it looked as though Japanese leasers would dominate the discussion. A change came when an elderly farmer rose and said:

I came to this district twenty years ago. $I$ live on the farm that $I$ bought then and where my six children were born. They go to the country school. Three years ago all their playmates were white children. Now all the children in that school except mine and those of one other farmer are Japanese. My white neighbors who have sold or leased their land to Japanese have gone to towns. They don't come in contact with these aliens. They simply take their money. I live among them, but am not one of them. I am living there without neighbors. Last week a Japanese family moved into a house across the road in front of my home. That means more Japanese children in the school. It means that my isolation from people of my own race is more complete and I too am here to "declare myself."

My farm is for sale. It is for sale to the first Japanese who will buy it. No white man will buy for none will go into a Japanese neighborhood. When I sell, my white neighbor will leave and it then becomes a Japanese community. When that happens the trade of that community will go into new channels. I have always traded at the white man's store, put my money in the white man's bank, but the Japanese will do neither. They trade with their own race.

The farmer was followed by a member of a commission firm that handled the melons of Japanese growers. He stated at the outset that if he was to consider his own financial interests he would remain silent, but he had decided it was his duty to give his views on the Japanese land problem. As his firm handled Japanese melons he obtained for them the money to finance growing 
and he knew, from being their banker, how in the short space of three years they had extended their control of melon production. He stated that with these people coöperation is an instinct, that the coöperation in that section was a continuation of their clan relation in Japan. These coöperative units usually had about twenty members. When one was in trouble the others helped him out, and it was a definite practice for those who had money to finance others and thus lift them out of the wage-earning into the employing class. He gave a score of instances where this financial help had been extended during the past season. He said that the Japanese had now secured a large enough share of the business to handle the selling of their melons in the future, that it was comparatively easy for them to make financial arrangements with commission houses in the east, and having done this they would be able to carry on as Japanese concerns.

His statement brought a complete change of sentiment in the meeting. Even the most defiant landowner realized that when the farms of that section were all under Japanese control through ownership or lease, they would be able to fix rents and land prices because white people will not go into sections dominated by Japanese. They saw that high rents were a temporary expedient to be paid long enough only to fix the status of the neighborhood as Oriental. Once this was done, there would be no further need for high rents or high prices. The resolution was signed by every landowner.

Previous to the movement for legislation, meetings like this were held all over California. It became evident that the voluntary action of isolated communities was not sufficient, that there were too many places where landowners were being tempted by money profits to ignore ultimate results and were creating a situation fraught with immensurable difficulty in the future.

The report of the Oriental problem by the State Board of Control shows that out of 3,893,500 acres irrigated, the Orientals control 623,753 acres, or about one-sixth and the Japanese alone control 458,056 acres, or about 16 per cent. This control has practically all been secured in the last ten years. The increase in acreage has been 412.9 per cent and the market value of the crops produced by Japanese has increased over tenfold, much of the work being done by hired white labor. With certain products like small fruits, they now have such a monopoly that they are able to dictate prices and control local markets.

San Joaquin County is one of the largest agricultural counties in the state. More than half of the irrigated land is controlled by the Japanese. Sacramento County has the state capital. It ought to be a permanent center of white civilization, but more than half of the irrigated land in that county is farmed and controlled by the Japanese, either as owners or lessees. The growth of their gardens and orchards in Sonoma, Santa Clara, and Solano counties is being watched by white farmers with ever increasing apprehension.

Japanese Evade and Ignore Laws and Public Opinion

What makes this growth more ominous is the fact that it has occurred while the "Gentlemen's Agreement" was supposed to exclude laborers. It confers no right to own agricultural land, yet in ten years there has been over 100 per cent increase in numbers and more than half of these newcomers have flocked to the country. Farm purchases could only be made through evasion of the law passed in 
1913. The Japanese have evaded it by every device which the best lawyers could invent. Japanese farmers have come to California knowing they were not wanted. They have bought land knowing it was contrary to the spirit of the law and the wishes of the people of California. In this they have shown the same spirit as in Korea and China. Yet, when these evasions became so notorious and the economic struggle so severe that white farmers sought to so amend the law as to end these aggressions, the Japanese used their thirtynine associations and all of their influence to create sympathy for a sensitive, diffident people who were only seeking to contribute to this nation's wealth.

Nothing could be more misleading. The Japanese are crowding in here because rural California is a paradise compared to the hard conditions of agriculture in their own country. No one can blame them for trying to possess the land and the agriculture of this state, nor ought we to think it strange that the Japanese government should back them up in this endeavor by every device of its adroit, if somewhat devious, diplomacy.

The danger is that America will not understand what is taking place or realize the disaster which this migration is certain to bring if the movement is not stamped out at once. There is danger that this nation will be misled by catch phrases like "Race Equality," "Uplifting Asia" and "Personal Liberty."

In order to compete with the Japanese, the American farmer, who has to make his way by labor, must sacrifice rest, recreation and the giving of time to civic interests or the development of the higher life of a community. He must change his ideas of what is desirable in life and surrender inherited habits. Only by devoting all of the energy of himself, his wife and children to the hard task of making a living, can he pay the rents and do the other things necessary to withstand the rural competition of the Japanese. The thing which America ought to recognize is that requiring him to do this is not an advance but a backward step in our progress and it will not be made. The American subjected to this competition will go into the cities or to other countries and the Japanese will continue to displace him as he has been displacing him during the last ten years.

These statements are made with no personal dislike for the Japanese, nor have I met with any evidence of a personal hatred toward them. On the contrary, the people of California have a high regard for their achievements, their industry and their surprising cleverness, but this does not blind the people in direct contact with them to what is going on or to the social and political dangers which are being created by this rapid absorption of farming land.

The land problem of California presents a new issue to America. The state seeks to check the immigration of people who come here for their racial and individual advantage, who seek to create little Japans with schools, newspapers, religion and language of the country they left. They bring a civilization many centuries old which they regard as superior to ours. They retain a loyalty to their own country, to its institutions and life, which prevents their becoming Americans or being assimilated into American life. Ownership of land enables them to secure these desired ends and what they have accomplished in the last ten years shows that unless something is done to check this progress, they will become the agricultural owners of California in a brief time as history runs. It is not 
a question of which is the superior race or which has the better culture. The objection to the Japanese is that with their coming Anglo-Saxon culture came in direct conflict with a Mongolian one. They can not live side by side and neither will give way to the other without a conflict.

\title{
Japanese in California
}

a Critical Examination of (1) Report of the California State Board of Control; (2) Letter by Governor Stephens to Secretary Colby;

(3) Hearings in California by the House Committee on IMMigRATION AND NATURALIZATION

\author{
By Sidney L. Gulick, D.D. ${ }^{1}$
}

Secretary, National Committee for Constructive Immigration Legislation, New York City

$\mathrm{T}$ IHE California State Board of Control at the request of Governor Stephens made a special investigation of the Japanese in California. Its report (of 225 pages) was issued June 19, 1920. The Governor conveyed it to the Secretary of State, Honorable Bainbridge Colby, with a covering letter of the same date. This letter forms the introduction to the volume containing the report.

The House Committee on Immigration and Naturalization held Hearings in California on the Japanese question, beginning in San Francisco July 12, continuing in other California cities, and concluding in the state of Washington. No official report of these Hearings has been published. They were, however, public meetings. Mr. R. W. Ryder has furnished the writer with an abstract and résumé of the proceedings covering 104 pages, parts of the testimony being given verbatim.

\footnotetext{
${ }^{1}$ Also Secretary, Commission on Relations with the Orient of Federal Council Churches of Christ in America since 1914. Author of: Evolution of the Japanese, Social and Psychic (1903), The White Peril in the Far East (1905), The American-Japanese Problem (1914), Working Women of Japan (1915), America and the Orient (1916), Anti-Japanese War-Scare Stories (1917), American Democracy and Asiatic Citizenship (1918).The EdITor.
}

The report of the Board of Control, the Governor's letter and the Hearings played a significant rôle in the California vote on the referendum Land Law. They will long be regarded as authoritative statements of the situation. An impartial and critical examination of their real character and value is desirable.

\section{SOME SURPRISES}

"The Japanese in Los Angeles are well housed and my reports say that they respond quickly to orders or suggestions from the authorities as to improvements or changes in their houses. Indeed, they are often more satisfactory in this regard than the lower class of Americans."

"One very noticeable feature in a Japanese labor camp where both American and Japanese laborers are employed is that the quarters provided for Japanese are generally better than those provided for the Americans. . . . Our experience with Japanese labor camp operators is that they will make any improvements necessary."

These two quotations are taken from the official reports to the Board of Con- 